\title{
COMMENTS
}

\section{WHAT ARE THE ALTERNATIVES TO CHICAGO?}

\author{
WESLEY J. LIEBELER*
}

In a recent issue of this journal, John Wiley and Herbert Hovenkamp commented on each other's views of the Chicago approach to antitrust. ${ }^{1}$ Wiley argued that Hovenkamp's earlier article ${ }^{2}$ had left the Chicago edifice largely untouched. ${ }^{3}$ Focusing on Aspen Skiing Co. $v$. Aspen Highlands Skiing Corp. ${ }^{4}$ and Bonjorno v. Kaiser Aluminum \& Chemical Corp., ${ }^{5}$ Wiley concluded that Hovenkamp's critique would not lead one to decide a single case differently from the Chicagoans. ${ }^{6}$ Operationally, at least, Hovenkamp's earlier efforts showed the Chicago School's strength, not its weakness. ${ }^{7}$ To avoid becoming a fellow traveler, however, Wiley then rejected the Chicago emphasis on efficiency, arguing that antitrust policy should be aimed at "preserving the wealth that ultimate or household consumers would realize by engaging in transactions in rivalrous markets."

In response, Hovenkamp discredited Wiley's distributive goal ${ }^{9}$ and, less successfully, attempted to rehabilitate his own analysis of Aspen Skiing and Bonjorno. ${ }^{10}$

It must please any Chicagoan to see critics shred each other on the issue of what is wrong with the Chicago School. Wiley thinks

* Professor of Law, University of California, Los Angeles. B.A., Macalester College, 1953; J.D., University of Chicago, 1957.

1. Hovenkamp, Chicago and Its Alternatives, 1986 DUKE L.J. 1014; Wiley, "After Chicago": An Exaggerated Demise?, 1986 Duke L.J. 1003.

2. Hovenkamp, Antitrust Policy After Chicago, 84 Mich. L. Rev. 213 (1985).

3. Wiley, supra note 1 , at 1003 .

4. 472 U.S. 585 (1985).

5. 752 F.2d 802 (3d Cir. 1984), cert. denied, 106 S. Ct. 3284 (1986).

6. Wiley, supra note 1 , at 1012 .

7. Id. at 1003.

8. Id. at 1012. Professor Wiley argued that "the goal of antitrust policy is to maintain or increase the size of consumers' surplus, not, as the Chicagoan would argue, to maximize the sum of consumers' and producers' surplus." Id.

9. Hovenkamp, supra note 1, at 1017-19. I agree with most of Professor Hovenkamp's comments on Professor Wiley's nonefficiency view of antitrust policy, but $I$ will not address that issue here.

10. Id. at 1015-17. 
Hovenkamp should appear as a blessing in disguise to the Chicagoans. ${ }^{11}$ They both look that way to me.

Despite their substantial talents, neither Wiley nor Hovenkamp has analyzed Aspen Skiing or Bonjorno correctly. I write principally to set them straight on that, but my discussion also shows how easy it is to make mistakes if we fail to structure our analysis around fundamental consumer welfare standards. Those standards require us to ask in each case whether the challenged conduct creates or increases the ability to restrict output. If it does not, there is no antitrust violation. If it does, we then ask whether that conduct has the potential to create or increase efficiency. Absent that potential, we have a per se violation. If, however, the challenged conduct has the potential to cut costs or otherwise increase productive efficiency, we must examine its market effect by balancing any losses from increased output restriction against any gains from increased efficiency. ${ }^{12}$ Challenged arrangements will be illegal only if those losses exceed such gains.

Readers should evaluate all points made by Professors Hovenkamp and Wiley, and other antitrust analysts as well, in the context of this analytical structure. How closely does their analysis follow this paradigm? If they reject it, what analytical structure do they use instead? Those who fail to follow this structure-or some clearly specified alternative-will soon find themselves mired in a morass of standardless subjectivity. This seems to be what happened to Professor Hovenkamp in his analysis of Aspen Skiing and Bonjorno. Wiley's comments do not completely remedy the problem. I will do so in my discussion of the two cases below.

\section{ASPEN SKIING}

Aspen Skiing Company (Ski Co) owns three of the four ski areas in Aspen, Colorado, including the famous Ajax Mountain. Ski Co opened Ajax in 1946. Primarily a mountain for advanced skiers, Ajax put Aspen on the skiing map. Another developer built Highlands in 1957, and it remains separately owned today. Buttermilk opened in 1958, and Ski Co bought it in 1964. In 1985, eighteen years after Ski Co built its third mountain-Snowmass-the Supreme Court held that Ski Co violated section 2 of the Sherman Act by refusing to continue a joint-ticket pro-

11. Wiley, supra note 1, at 1013.

12. See R. Bork, The ANTITrust Paradox 107-08 (1978) (using graph "to represent the trade-off problem in a merger that both creates power to restrict output and cuts costs"); Liebeler, Intrabrand "Cartels" Under GTE Sylvaria, 30 UCLA L. Rev. 1, 13-19 (1982) (same); Williamson, Economies as an Antitrust Defonse: The Welfare Tradeoffs, 58 AM. Econ. REv. 18, 21-23 (1968) (same). 
gram with Highlands. ${ }^{13}$ The Court affirmed a judgment based on a jury finding that Ski Co had monopolized the market for downhill skiing at Aspen. ${ }^{14}$

Under the joint-ticket program, skiers could buy a weekly ticket that could be used at any of the four Aspen ski areas. Proceeds from its sales were divided on the basis of the extent to which skiers used the different mountains. ${ }^{15}$ Highlands received $17.5 \%$ of net ticket revenues in $1973-74,18.5 \%$ in $1974-75,16.8 \%$ in $1975-76$ and $13.2 \%$ in $1976-77$. Ski Co offered to continue the joint ticket in 1977-78 if Highlands would accept $13.2 \%$ fixed percentage. Highlands wanted to continue on the basis of actual use, but eventually accepted a fixed $15 \%$ of net revenues for 1977-78. Ski Co tried to cut this to a fixed $12.5 \%$ for the next season. Highlands refused, and the joint-ticket program ended. ${ }^{16}$ Ski Co refused to cooperate with subsequent efforts by Highlands to create a substitute for the four-area ticket. Highlands' share of skiing in Aspen declined to $13.1 \%$ in $1977-78,12.5 \% \mathrm{~m} 1978-79$ and $11 \%$ in $1980-81.17$

Professor Hovenkamp views this case as "an example of strategic behavior that both raised a rival's costs disproportionately to those of the defendant and reduced the relative attractiveness of the rival's market offering while simultaneously producing no efficiency gains to the defendant." 18 These words say nothing about whether the challenged conduct created or increased anyone's power to restrict output. Yet Professor Hovenkamp believes them sufficient to describe a violation of section 2 of the Sherman Act. ${ }^{19} \mathrm{He}$ is obviously not following the standards of the consumer welfare paradigm set forth above. What then is the standard on which he bases his conclusions?

Wiley suggests that ending the four-area ticket may have created efficiency by keeping Highlands from free riding on Ski Co's national

13. 472 U.S. 585, 605, 611 (1985). My discussion of this case assumes the correctness of this finding. The idea that Aspen is a separate ski market, however, is absurd. Skiers choose to patronize "destination" ski areas-those which they visit to ski for periods usually longer than a weekend-on a national or even international basis. See Wiley, supra note 1 , at 1007 \& n.19.

14. 472 U.S. at 611.

15. In earlier periods, the joint ticket consisted of booklets containing coupons that could be redeemed for tickets at the different areas. Revenues from ticket sales were distributed on the basis of the number of coupons collected by each mountain. Later, the booklets were replaced by an "around the neck" all-Aspen ticket and revenues were divided on the basis of surveys of actual use of the different mountains. Id. at 589-90.

16. Id. at 592-93.

17. Id. at 594-95.

18. Hovenkamp, supra note 2, at 282 (footnote omitted).

19. See id. (The conduct involved in Aspen Skïng was "predatory" despite the fact that it "did not require the defendant to sustain short-term losses in order to receive long-term gains."). 
advertising. ${ }^{20} \mathrm{He}$ also attacks Hovenkamp's claim that because some skiers prefer access to four mountains over access to three, the demise of the four-mountain ticket must have reduced overall demand for skiing at Aspen, which somehow proves Ski Co violated the Sherman Act. ${ }^{21}$ Using his Chicago voice, Wiley responds that the increased national advertising Ski Co could conduct after eliminating free riding might increase demand for a three-mountain ticket above that previously enjoyed by the four-mountain ticket. Wiley seems to beheve, however, that an elaborate econometric study would be needed to estabhish this free-rider defense. Absent such proof, the free-rider analysis would remain only an "inventive" possibility. ${ }^{22}$ Wiley does not suggest, however, that a similar empirical study be conducted to show that the exclusion of Highlands increased market power in the first place.

All this misses the main point, which Hovenkanp buries in his rush to charge Chicagoans with being blind to "strategic behavior."23 Hovenkamp concludes that the Sherman Act is violated by conduct that raises a rival's costs without creating efficiency-whether or not market power has increased. ${ }^{24}$ Absent a per se violation, however, the legality of Ski Co's behavior must turn on market effect, making it necessary to ask whether such behavior created or increased the power to restrict output. If it did, we then ask whether the losses from that increase in market power are greater or less than any gains that may have resulted from increased efficiency. The efficiency question does not arise, however, unless plaintiff first shows that the challenged conduct somehow increased defendant's ability to restrict output and thereby raise prices. ${ }^{25}$ The problem with Hovenkamp's position is that we cannot conclude that market power increased from a showing that Ski Co's conduct increased Highlands' costs.

20. Wiley, supra note 1, at 1005. See also Easterbrook, On Identifying Exclusionary Conduct, 61 Notre DAME L. REv. 972, 975-76 (1986) ("[Ski Co] might believe it was entitled to compensation for providing Highlands with a ready pool of customers . ..."); Easterbrook, Workable Antitrust Policy, 84 Mich. L. REv. 1696, 1710-11 (1986) (proposed adjustments in receipts sharing "may have been no more than a way of requiring [Highlands] to pay for access to the pool of customers that were [sic] produced by [Ski Co's] hard work, expensive advertising, improvements, and so on").

21. Presumably, the idea is that Ski Co would hurt itself by reducing overall demand at Aspen and that its willingness to do so showed exclusionary or predatory intent. The move to a threemountain ticket may have been associated with a dispute over division of locational rents or may have created real efficiencies; I cannot tell which. See discussion infra note 46 . But it surely could not have been associated with anything that made the demand curve for multi-mountain tickets less elastic.

22. Wiley, supra note 1 , at 1007 .

23. Hovenkamp, supra note 2 , at $256,260-64$.

24. Id. at 274-80.

25. See, e.g., Cascade Cabinet Co. v. Western Cabinet \& Millwork Inc., 710 F.2d 1366, 1371 (9th Cir. 1983). 
There is indeed no plausible theory of this case under which we can conclude that Ski Co's conduct created or increased market power. There was a monopoly over multi-mountain tickets at Aspen before Ski Co ousted Highlands and one after that event.26 Excluding Highlands could not increase the power of that monopoly. If anything, it would reduce it. The breakdown of contract relations between Ski Co and Highlands tended to increase competition at Aspen-not decrease it.27 Unless Ski Co's refusal to deal with Highlands on a four-mountain ticket reduced competition, it could not violate an antitrust law based on the consumer welfare paradigm. ${ }^{28}$

If plaintiff could not show that its exclusion increased Ski Co's power to restrict output, there is no need, from a strictly legal standpoint, to examine possible efficiency or other explanations for that exclusion. It will advance our understanding of business practices, however, and perhaps of the proper scope of the antitrust laws, to seek an economic explanation of Ski Co's behavior. Such an explanation would also have been useful in convincing the jury that Ski Co's conduct was not "unfair" to Highlands.

Professor Wiley's efficiency explanation may be correct. Highlands may have been a potential free rider on Ski Co's future advertising. I suspect, however, that Highlands would have been happy to contribute to advertising campaigns in amounts proportional to its percentage take from sales of the four-mountain ticket if it had continued to receive proceeds from such sales based on actual usage of the four mountains. The transaction costs of solving the free-rider problem in that way are so low as to suggest that something else may have been involved.

To get some idea of what that something else might have been, let us go back to 1945 when there were no ski areas at Aspen. Developing Ajax into a major ski area primarily for advanced skiers would increase land values in Aspen, particularly the value of land close to Ajax itself. Such increases in value are called locational rents. The developers of Ajax

26. The initial monopoly took the form of a joint venture between Ski Co and Highlands to sell a four-mountain ticket. In offering that ticket, they set its price and divided the revenues from its sales. 472 U.S. at 591 . This eliminated all competition in the multi-mountain ticket market.

27. Highlands' exclusion from the multi-mountain ticket market probably did not increase short-run competition substantially. Although Highlands was unable to structure a multi-mountain ticket that included Ski Co's mountains, it did try. Furthermore, Highlands' inability to offer a multi-mountain ticket with Ski Co increased its incentives to build or induce others to build other ski areas to compete with Ski Co in the multi-mountain Aspen ski market. The effects of these factors are difficult to judge; they may not have been great, but they were there. If the demise of the fourmountain ticket had any effect on competition, it must have increased it somewhat. It certainly could not have reduced it.

28. This conclusion is based on facts as to which there is no dispute. In this view of the case, there was no issue for the jury; defendant should have prevailed on a motion for summary judgment. 
surely would not have violated the antitrust laws if they had acquired land that increased in value after Ajax had been successfully developed, thereby obtaining some of those locational rents for themselves.

The dispute between Highlands and Ski Co appears to have concerned the division of such locational or "local monopoly" rents. ${ }^{29}$ To see this, consider the development of other mountains after Ajax had become successful. A new area for less advanced skiers might have benefited from its proximity to $A$ jax, just as might a new restaurant. ${ }^{30}$ Many top-flight skiers came to Aspen to ski Ajax; their less able associates could ski at the new area. Highlands must have gained from being near Ajax, ${ }^{31}$ but Ajax probably gained from Highlands too. More good skiers would come to Aspen to ski Ajax because Highlands was available for their less accomplished friends. The presence of both mountains made both more valuable than either would have been alone.

Highlands' value would decline, however, if ski areas competitive with it (but not with Ajax) could be developed later, as indeed they were. Ski Co acquired Buttermilk in $1964^{32}$ and opened Snowmass-a balanced mountain eight miles from the village-in 1967.33 By 1967, therefore, Ski Co owned a complementary set of ski areas that provided a broad variety of skiing conditions. Highlands' value to a product providing a balanced mix of skiing was now less than it had been when the jointticket program began in 1962. Yet Highlands continued to share in the proceeds of that program on the basis of usage through the 1976-77 ski season. ${ }^{34}$

Just how the proceeds from a four-mountain ticket "should" have been divided is an interesting question-and one important to understanding the "economic and business stuff" 35 that led to this case. In

29. Such rents would exist to the extent that Ajax (or Aspen itself for that matter) was more attractive than (differentiated from) other mountains or ski resorts. The existence of such rents does not imply that Aspen was a separate market or submarket for antitrust purposes any more than the market for Cadillac automobiles, for example, is separate from the general autornobile market. Nor do such rents have anything to do with Ski Co's treatment of Highlands; the rents would be there regardless of whether Highlands was part of the multi-mountain ticket program.

30. These locational rents would accrue to landowners rather than ski-area developers if there were only one location for another ski area or if all such locations were commonly owned. Subsequent developments suggest, however, that this was not the case.

31. Highlands was $1 \frac{1}{2}$ miles from Aspen village; its runs were $25 \%$ beginner, $50 \%$ intermediate and $25 \%$ advanced; and it was a more "balanced" mountain than Ajax. 472 U.S. at 587 n.2, 588 n.3.

32. Id. at $588 \mathrm{n} .4,589$. At first Buttermilk was primarily for beginning and intermediate skiers; more difficult runs were added later. Buttermilk's base area is $2^{1 / 4}$ miles from Aspen village. Id. at 588 n.4.

33. Id. at 588 n.5.

34. Id. at 592 .

35. White Motor Co. v. United States, 372 U.S. 253, 263 (1963). 
considering this question, we must remember that the main attraction at Aspen has always been Ajax. Although each of the other areas also contributed something to the overall Aspen image, the marginal contribution of each declined as other areas were built. In other words, Highlands contributed less after Buttermilk and Snowmass were built than when it shared the spotlight with Ajax alone. Throughout this whole drama, however, Ajax was-and remains-the star of the show.

In this context, let us put ourselves in Ski Co's position. We know that Aspen is a "destination" ski center. We cannot survive without attracting people from distant places to ski for extended periods of time. ${ }^{36}$ We also know that Ajax is the principal attraction. Furthermore, we own two of the other three areas that provide more varied, less-demanding runs, and we know that the net proceeds of the multi-mountain ticket sales have been split on the basis of actual use, even though the number of "lesser" ski areas has increased. Might we not begin to suspect that we are giving Highlands too much?

That suspicion is supported by the Court's statement that:

Without a convenient all-Aspen ticket, Highlands basically "becomes a day ski area in a destimation resort." Highlands' share of the niarket for downhill skiing services in Aspen declined steadily after the 4-area ticket based on usage was abolished in 1977: from 20.5\% in 19761977 , to $15.7 \%$ in $1977-1978$, to $13.1 \%$ in $1978-1979$, to $12.5 \%$ in $1979-1980$, to $11 \%$ in $1980-1981 . .^{37}$

Highlands argued that Ski Co engaged in exclusionary behavior by "forcing plaintiff out of the four-area ticket by requiring that revenues be divided below plaintiff's market share." 38 By itself this raises no antitrust issue even if true. We pursue the matter, however, to clarify the economics of the transaction. Highlands obviously wants us to believe-as the jury and the various courts involved in this case apparently did-that it somehow had a right to continue participating in a four-mountain ticket and to receive proceeds from its sale on the basis of its market share, that is, based on actual usage by skiers after they had arrived at Aspen. We may evaluate this claim by considering the market value of a ski area like Highlands in an area like Aspen to someone trying to create and market a multi-mountain ticket.

Suppose first that all four ski areas are separately owned and some

36. If you have never been to Aspen, look at a map of Colorado to see how remote this village of some 2600 souls is. Clearly, it cannot survive on the business of weekend skiers, as can areas closer to large population centers.

37. 472 U.S. at 594-95 (citation omitted). Buttermilk substantially increased its market share at Highlands' expense. Id. at 595 n.16.

38. Aspen Highlands Skiing Corp. v. Aspen Skiing Co., 738 F.2d 1509, 1517 (10th Cir. 1984), aff'd, 472 U.S. 585 (1985). 
outside party seeks to establish a multi-mountain ticket. ${ }^{39}$ What is the minimum amount it would liave to pay each mountain to get it to participate? Note first that the market for creating multi-mountain tickets is competitive; a promoter could not earn more than a competitive rate of return..$^{40}$ Note next that part of the market is not competitive. There is no good substitute for Ajax: while skiers will move readily between Highlands, Buttermilk and Snowmass, it will take more to move them from these mountains to Ajax, and vice versa. The fact that Highlands, Buttermilk and Snowmass are good substitutes for each other, however, means that absent collusion we may take the market for lesser ski areas at Aspen to be competitive.

Assuming competition between the three lesser mountains, a promoter could get any of them to join the multi-mountain ticket venture by paying an amount that would make the recipient just slightly better off than it would be if it did not join the venture. The three lesser mountains' fear of being left out of a multi-mountain ticket would force the price a promoter would have to pay any of them down to the point where the lesser mountain would be just slightly better off by joining than not joining. There is no reason to suppose that such a price would be anywhere near as high as one based on actual use of the mountain. This analysis is consistent with Ski Co's view that the old arrangement was "siphoning off revenues that could be recaptured by Ski Co. if the ticket was discontinued." 41 To the extent that there is a "fairness" dimension to this case, it suggests that the split based on usage had been "unfair" to Ski Co and undercuts any claim that Ski Co was mistreating Highlands by pushing its share of multi-mountain ticket sales toward what it would be under competition.

This analysis is not affected by the fact that Ajax, Buttermilk and Snowmass were jointly owned. I had originally suspected that Ski Co may have been trying to extract quasi-rents from Highlands and that its power to do so was increased by its ownership of Buttermilk and Snowmass. ${ }^{42}$ But that seems not to be the case. It appears that competi-

39. The result would not be different if the ticket were promoted by any of the individual ski areas. See A. Alchian \& W. Allen, Exchange and Production: Competition, CoordinaTION, AND CONTROL 80-81 (2d ed. 1977) (initial ownership of automobiles irrelevant to final market cquilibrium). I consider below the question of whether the common ownership of Ajax, Buttermilk and Snowmass makes any difference. See infra notes $42-43$ and accompanying text.

40. If one promoter offered the mountains less in an attempt to earn supra-competitive returns, another promoter would decrease those returns by offering the mountains more.

41. 472 U.S. at 592.

42. See Klein, Crawford \& Alchian, Vertical Integration, Appropriable Rents and the Competitive Contracting Process, 21 J.L. \& Econ. 297, 298 (1978) ("The quasi-rent value of the asset is the excess of its value over its salvage value, that is, its value in its next best use to another renter."). 
tion between Buttermilk, Snowmass and Highlands would enable Ajax to extract all the benefits of its "natural monopoly". Competition would force returns to any lesser mountain down until they were just above what they would be if that mountain stayed out of a multi-mountain ticket arrangement. Ski Co's ownership of Buttermilk and Snowmass could not enable it to force Highlands' split below that level. Given the natural monopoly held by Ajax, Ski Co was not exercising any "power" against Highlands that would not have been exercised against it by a perfectly competitive bidding situation. To punish Ski Co under the antitrust laws in these circumstances seems perverse indeed. ${ }^{43}$

My discussion of Aspen Skiing illustrates the case was wrongly decided and has to date been poorly analyzed by other commentators. It also shows the weakness of analysis based on the idea of strategic behavior to raise rivals' costs. ${ }^{44}$ As I have argued elsewhere, ${ }^{45}$ this approach adds nothing to traditional horizontal analysis and has the disadvantage of leading attention away from such fundamentals toward verbal formulations bound to end in error-as they did in Professor Hovenkanip's treatment of this case.

Aspen Skiing does not involve the creation or protection of a nionopoly. It is nothing more than a contract dispute over the allocation of proceeds from the sale of multi-mountain tickets. ${ }^{46}$ While my analysis

43. The fact that Ski Co owned both Ajax and at least one of the lesser mountains, however, would prevent all of the lesser mountains from colluding to prevent competition among themselves for membership in the multi-mountain ticket venture. Such collusion could raise their returns and reduce those of Ajax, particularly if it were difficult to build any new lesser mountains, as government regulation apparently had made it. See 472 U.S. at 588-89. This, however, does not affect my analysis.

44. See Hovenkamp, supra note 2, at 274-80; Krattenmaker \& Salop, Anticompetitive Exclusion: Raising Rivals' Costs to Achieve Power over Price, 96 YALE L.J. 209 (1986).

45. Liebeler, Exclusion and Efficiency, 1987 REg. MAG. no. 3/4, at 34.

46. There is another possible efficiency explanation. The relations between Ski Co and Highlands in terms of producing a four-mountain ticket are vertical in nature; the ski areas orwned by both firms are inputs to the final product. Because their assets are so highly specialized to each other, the parties' relations can be analyzed in terms of bilateral monopoly. Think of Ski Co as purchasing Highlands' services, combining them with its own mountains and then selling the final product-the four-mountain ticket-to the public. My analysis in the text suggests that Ski Co was paying Highlands more than a competitive price for its input. Ski Co could have concluded that both it and buyers of multi-mountain tickets at Aspen would be better off if it cut costs by ceasing to pay monopoly prices for Highlands' services. Dropping the fourth mountain would certainly reduce the value of the final product to some consumers, but it would also imply a price cut. The price cut comes from two sources: (1) the change in the shape of the demand curve associated with dropping the fourth mountain implies a price cut to reach a new profit maximizing price, and (2) a price cut is implied as marginal costs decline once Highlands is no longer paid monopoly prices for its input. Costs may have been reduced and/or prices cut enough so that economic efficiency increased even though the quality of the product declined.

My point may be easier to see in another context. Suppose a court held Peugeot automobiles to be a relevant market. Suppose all Peugeots had been sold with power windows, which Peugeot had 
suggests that Highlands had been getting more than its competitive share of those proceeds for a long time, the correctness of that view is not relevant to the basic point that the case flowed from a contract dispute and had nothing to do with an increase in market power. ${ }^{47}$ Ski Co should not, therefore, have been held to have violated the antitrust laws.

Professor Hovenkamp should not be surprised that it takes a Chicago economist to explain these cases to the parties and their lawyers. ${ }^{48}$ It apparently takes one to explain them to Professor Hovenkamp as well.

\section{BONJORNO}

Bonjorno v. Kaiser Aluminum \& Chemical Corp., ${ }^{49}$ grew from the relations between Kaiser Aluminum and the Columbia Metal Culvert Company (Columbia), of which the Bonjornos were the sole stockholders. Columbia began making aluminum drainage pipe in 1962, at first buying all of its raw materials from Kaiser, as Kaiser apparently required it and other independent pipe fabricators to do. ${ }^{50}$ The parties fell out in 1972, after which Columbia bought aluminum from Alcoa and Reynolds. Kaiser then opened a pipe plant forty miles from Columbia. Columbia claimed that as a result it lost money and was forced to stop production in 1975. Its assets were sold to a third party in 1978, and in 1981 the third party sold what was left to Kaiser.

Columbia claimed that Kaiser had attempted to monopolize and did in fact monopolize a market defined as aluminum drainage pipe in the Mid-Atlantic region of the United States. After three trials and two appeals, the United States Court of Appeals for the Third Circuit upheld judgment for Columbia based on a jury verdict. The claim that Kaiser

been buying from an outside supplier, a monopolist. After a time, Peugeot objects to paying monopoly prices for window assemblies. It asks its supplier to cut prices to a competitive level (25\% less than the old price). The supplier refuses. Peugeot terminates and installs crank windows in all of its cars. Would Professor Hovenkamp argue that this violates the antitrust laws? Does the answer depend on whether Peugeot reduces car prices after shifting to crank windows? By how much? How does this example differ from Aspen Skiing?

The validity of this efficiency explanation depends on whether Ski Co and Highlands were charging a joint profit-maximizing price before the termination. If they were, the dispute is exclusively over division of rents. If they were not, the termination may create real efficiencies. See Liebeler, supra note 12, at 20-23 (describing theory of sucessive monopoly).

47. If consumers preferred a four-mountain ticket to a three-mountain ticket by a sufficient margin to cover the costs of transacting between Ski Co and Highlands, that ticket would eventually have reappeared. Highlands, however, would have been paid less than the amount determined by usage. Highlands was able to avoid that result by winning an antitrust case it should have lost.

48. Hovenkamp, supra note 1 , at 1014.

49. 752 F.2d 802, 805 (3d Cir. 1984), cert. denied, 106 S. Ct. 3284 (1986).

50. Id. at 808. There was testimony of threats from Kaiser to open a pipe fabrication plant across the street from Columbia if Columbia bought aluminum elsewhere and to terminate its relations with Columbia if it "saw so much as one pound of metal from another producer." Id. 
had squeezed Columbia by raising the price of aluminum for pipe and cutting the price of pipe was the centerpiece of the litigation. ${ }^{51}$ The court concluded:

When a monopolist competes by denying a source of supply to his competitors, raises his competitor's price for raw materials without affecting his own costs, lowers his price for the finished goods, and threatens his competitors with sustained competition if they do not accede to his anticompetitive designs, then his actions have crossed the shadowy barrier of the Sherman Act. 52

As in Aspen Skiing, this case presents an mitial problem with market

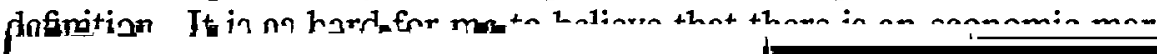


Wiley deals effectively with Hovenkamp's argument that the Chicago view of price squeezes is incomplete because such squeezes may be used to extract quasi-rents from vertically related firms with high sunk costs. ${ }^{58}$ It is worth adding that Chicagoans have developed some of the most important analysis of rent appropriation ${ }^{59}$ and have used that analysis to offer efficiency explanations for many arrangements that might otherwise seem anticompetitive. ${ }^{60}$ There are no plausible grounds for criticizing Chicagoans on this point.

There is a more fundamental problem with Professor Hovenkamp's view of antitrust law which I believe gives rise to his spurious bits of vitriol against the Chicago School. The problem appears in a number of different places, but a good example can be found in his rejoinder to Wiley on the quasi-rents point. Hovenkamp writes that he "reserve[s] the possibility-something that many Chicagoans appear to be unwilling to do-that some vertical relationships are not efficient, and [suggests] that one place this is likely to occur is where sunk costs are high."61

Let us accept Hovenkamp's statement at face value, even though there is every reason not to do so. ${ }^{62}$ Many things in this world are not efficient, but that does not mean they violate the antitrust laws. A market-based antitrust law cannot be violated unless the challenged conduct creates or increases market power. Even then, such conduct could be illegal only if losses from increased market power exceed efficiency gains. ${ }^{63}$ Once again Professor Hovenkamp has cut himself loose from the consumer welfare standard without specifying the analytical structure he is using instead. Let us, however, apply the consumer welfare standard to Bonjorno.

As in Aspen Skiing, the conduct challenged in Bonjorno by itself could not have increased anyone's ability to restrict output. ${ }^{64}$ Assume all

58. Wiley, supra note 1, at 1008-69. Briefly, Professor Wiley points out that such behavior is merely an attempt to redistribute income that will not have any efficiency consequences either currently or in the future. I would add that such conduct does not create or increase market power.

59. Sce, e.g., Klein, Crawford \& Alchian, supra note 42 (discussing appropriable quasi-rents as a factor leading profit-maximizing firms to choose vertical integration over inter-firm contracting).

60. See, e.g., Liebeler, 1984 Economic Review of Antitrust Developments: Horizontal Restrictions, Efficiency, and the Per Se Rule, 33 UCLA L. Rev. 1019, 1022-30 (1986) (using analysis of opportunistic behavior to explain efficiency of ancillary restrictions on competition).

61. Hovenkamp, supra note 1 , at 1017.

62. Even after his lashing from Wiley, Hovenkamp does not have it right. The presence of high sunk costs is one of the conditions that is likely to lead to efficient vertical integration-precisely to avoid the problem of opportunistic extraction of quasi-rents about which Hovenkamp complains in lis analysis of Bonjorno. See Hovenkamp, supra note 2, at 266-74; Liebeler, supra note 60, at 1022 30.

63. See sources cited supra note 12.

64. It might be argued that the original exclusive-dealing arrangement and the ownership vertical integration that replaced it were part of a manufacturers' cartel and could increase market power 
the evil alleged about Kaiser were true. The fact remains that there was one fabricator of aluminum pipe-Columbia-in the Mid-Atlantic region when Kaiser started its vendetta, and there was one such fabricator in that market when the campaign ended-Kaiser. The net result of the challenged conduct was that Kaiser replaced Columbia as the sole fabricator of aluminum pipe in the Mid-Atlantic region. It is hard to see how that fact by itself could have increased market power.

Competitive conditions in this gerrymandered market were no worse after Kaiser had driven Columbia to the wall than they would have been had Kaiser merged with Columbia. In fact, they were not as bad. Columbia's assets remained outside Kaiser's control for six years after Columbia went under; Kaiser would have obtamed those assets at once if the parties had merged. Moreover, the market had the benefit of competition between Kaiser and Columbia from 1973-1975 (the period between the time Kaiser built its pipe plant and the time Columbia expired). Furthermore, it seems unlikely that anyone would have challenged such a merger, which was strictly vertical and accordingly would not have increased market power. If a merger would not violate the antitrust laws, there is no reason why Kaiser's actual conduct should fare worse. That is, of course, unless the antitrust laws are being used to protect competitors instead of competition-which could well be true in this case.

Because Kaiser could not increase its market power by replacing Columbia in the fabrication market, this case should have been dismissed or decided for defendant on motion. As in Aspen Skiing, however, the question remains for the intellectually curious and for those who wish to improve their performance in front of juries as to why Kaiser replaced Columbia-apparently on the basis of its refusal to deal exclusively. If this replacement could not increase market power, there must be some other explanation for it.

The basis of a plausible explanation appears in the court's opinion, although no one seems to have noticed. The court of appeals found that "Kaiser was the largest producer of coil used for pipe [and] it was the only major manufacturer who had an extensive marketing and engineering staff who actively promoted and studied the uses of aluminum pipe." 65

by reinforcing the cartel. See Telser, supra note 57 , at $96-98$. That possibility cannot be excluded a priori; it is a question of fact. But that was not the basis of the claim in Bonjorno. The only claim that survived in that case was that Kaiser had monopolized the market for aluminum drainage pipe in the Mid-Atlantic region of the United States. Bonjorno, 752 F.2d at 805 .

65. 752 F.2d at 809 . 
The obvious question is how Kaiser recovered a return on the investment it had made in this "extensive marketing and engineering staff." 66 Most probably, it did so in the form of increased sales of the aluminum used to fabricate pipe. But that created a classic free-rider possibility-Kaiser's costly marketing and engineering staff "promoted and studied the uses of aluminum pipe,"67 but, absent exclusive dealing, Alcoa and Reynolds could sell the aluminum to make the pipe, presumably at a lower price because they did not bear the same costs. ${ }^{68}$

Columbia and other "independent" fabricators as well as the other aluminum manufacturers could free ride on Kaiser's efforts simply by buying and selling non-Kaiser aluminum and using it to fabricate pipe. Kaiser faced two apparent alternatives if it could not prevent the free riding by enforcing exclusive-dealing arrangements with the fabricators. It could disband its marketing and engineering efforts (and presumably take a loss on investments already made), or it could integrate by ownership into fabrication and continue its efforts in the pipe market. Kaiser chose the latter and for its efforts was held to have violated the antitrust laws-even though its conduct did not increase market power but rather increased efficiency and presumably provided benefits both to Kaiser and to society.

This efficiency explanation is not technically needed; Kaiser's conduct could not have increased market power in the first place. It is useful to offer such explanations, however, particularly in jury cases. Without this free-rider analysis, Kaiser's treatment of Columbia looks bad. Kaiser's image would not be much improved by my economic analysis of the market-power point. But an explanation that shows others taking advantage of Kaiser's efforts to find new uses for and to promote the sale of aluminum drainage pipe casts Kaiser in a completely different light—one that would have made it much easier for Kaiser to have won.

Kaiser's lawyers apparently did not advance this explanation, much

66. Id.

67. Id.

68. The situation here is similar to that in FTC v. Brown Shoe Co., 384 U.S. 316 (1966). Brown Shoe Company gave shoe retailers inventory control systems, plans for new shoe stores, the services of a Brown field representative and access to group insurance. In return, it required the retailers to sell Brown shoes in available lines and styles. Id. at 318. These quasi-exclusive dealing arrangements seem to have been designed to permit Brown Shoe Company to recover its investment in the services described; Brown Shoe Company (and the contracting retailers) apparently believed provision of those services would sell more shoes than a lower price. The FTC struck down this efficiency-creating arrangement, and the Supreme Court affirmed the decision. Id. at 322. This is one of many Warren Court antitrust decisions that would be decided differently under Chicago analysis, Professor Hovenkamp to the contrary notwithstanding. See Hovenkamp, supra note 1, at 1017. 
to Professor Hovenkamp's disquiet.69 But Kaiser's lawyers are not the only ones remiss. Oliver Williamson constructed and presented to the court an elaborate explanation of Kaiser's attempted exclusive dealing based on a theory of collusion between Kaiser, Alcoa and Reynolds. ${ }^{70}$ Williamson's failure to note the simpler efficiency explanation may have liad something to do with the source of his interest $m$ this case, but that cannot be true of Professor Hovenkamp, who did not focus on an efficiency explanation even though he was not employed by plaintiff.71 Professor Wiley liedged by saymg he could not say the Chicagoans are correct because lie liad not done the work necessary to establish the true reasons for Kaiser's behavior. ${ }^{72}$ Presumably, however, both Hovenkamp and Wiley read the case. The perfectly obvious basis for my efficiency explanation is in plain sight on page 809 of the federal reporter. ${ }^{73}$

\section{CONCLUSION}

Even though the Chicagoans have been emphasizing output restriction and efficiency for a generation, highly competent folks are still letting fairly obvious points get by thein. This is a sad state of affairs not easy to understand. It is easier to understand, however, as to practicing lawyers than as to academics. Many lawyers seein reluctant to emphasize bare-bones economics such as I liave used above. This kind of analysis remains foreign to the legal language and concepts with which lawyers are used to dealing. Moreover, many judges are still unfamiliar with or hostile to this kind of analysis. Although this is no excuse for the performances in many of these cases, it may explain part of it. ${ }^{74}$

Academics, however, should not be constrained in this way. Their job is to analyze and explain the cases, even if that takes them outside traditional legal categories or if it offends some judge hostile to economic analysis. Professor Hovenkamp seems to want to discredit the Chicago

69. Hovenkamp, supra note 1 , at 1014-15.

70. 752 F.2d at 809-10.

71. Ronald Coase has noted that "if an economist finds something-a business practice of one sort or other-that he does not understand, he looks for a monopoly explanation." Coase, Industrial Organization: A Proposal for Research, in POLICY Issues AND RESEARCH OPPORTUNITIES IN INDUSTrial Organization 59, 67 (V. Fuchs ed. 1972). Professor Williamson has added that "[o]fficials charged with enforcing antitrust laws are even more inclined to find monopoly purposes lurking in unfamiliar or unconventional business practices." Williamson, Book Review, 83 YALE L.J. 647, 661 (1974). Apparently economists who testify for plaintiffs also have difficulty perceiving the efficiency aspects of defendants' arrangements.

72. Wiley, supra note 1 , at 1011 .

73. Bonjorno, 752 F.2d at 809 (concerning Kaiser's return on its investment in its "extensive marketing and engineering staff"').

74. Uhlmann's Law-named after Michael Uhlmann, now a Washington, D.C., attorneymay explain more: "If stupidity is an adequate explanation, seek no further." 
School, and while Wiley refutes Hovenkamp's arguments, he too disputes some fundamentals of Chicago doctrine. To the extent that Chicago analysis emphasizes basics such as losses from output restriction and gains from productive efficiency (opposite sides of the same efficiency coin), Hovenkamp's and Wiley's desire to distance themselves from things Chicago may lead these critics to shight such fundamentals.

The principal problem, however, lies in the approach that the critics would substitute for Chicago analysis. Hovenkamp particularly is caught up in the idea that the thin gruel associated with buzzwords like "strategic behavior" and "raising rivals" costs" offers a significant new approach to antitrust analysis. ${ }^{75} \mathrm{He}$ believes the "cutting edge" of antitrust scholarship is associated with such ideas. ${ }^{76}$ Nothing could be further from the truth.

I have elsewhere expressed my view that an analysis based on raising rivals' costs contributes nothing to traditional horizontal antitrust analysis and has the disadvantage of emphasizing injury to competitors rather than to competition. ${ }^{77}$ Once an analyst starts down this path, the possibilities for error are almost endless. Consider, for example, Professor Hovenkamp's recent proposal to expand the per se rule to cover arrangements that raise rivals' costs without creating an efficiency that Hovenkamp can identify. ${ }^{78}$ This idea runs counter to the consumer welfare approach which Professor Hovenkamp seems to adopt generally. The per se rule- which still has not been confined to appropriate bounds after a generation of expansion by courts that knew little about economics and cared less-can be justified only in cases where challenged conduct is almost certain to restrict output without creating efficiencies. ${ }^{79} \mathrm{It}$ has not been shown-nor could it be shown-that arrangements that raise rivals' costs necessarily (or even probably) have those effects. ${ }^{80}$

75. Hovenkamp, supra note 2 , at $260-83$. Professor Wiley does not make this mistake. His emphasis on maximizing consumer surplus may be partly responsible for his failure to focus sufficiently on productive efficiency, but it cannot explain his failure to ask whether the challenged conduct in Aspen Skiing and Bonjorno created or increased market power in the first place.

76. Id. at 216.

77. Liebeler, supra note 45.

78. Hovenkamp, Antitrust Policy, Restricted Distribution, and the Market for Exclusionary Rights, 71 MinN. L. REv. 1293, 1317 (1987).

79. The per se rule is properly applied only when the challenged conduct "appears to be one that would always or almost always tend to restrict competition and decrease output," not one "designed to "increase economic efficiency and render markets more, rather than less, competitive." " Broadcast Music, Inc. v. Columbia Broadcasting Sys., 441 U.S. 1, 19-20 (1978) (quoting United States v. United States Gypsum Co., 438 U.S. 422, 441 n.16 (1978)).

80. The category of arrangements that raise rivals' costs is very broad, including our entire system of property rights. To say that $X$ owns an orange grove, for example, means that $X$ has an enforceable right to exclude rivals from taking his oranges without consent. This property right raises $X$ 's rivals' costs and enables $X$ to charge a higher price for oranges. This is, indeed, the 
Thus, per se treatment of such arrangements is totally inappropriate.

Professor Hovenkamp writes that "as far as [he] know[s] no one has ever provided a rational efficiency explanation for contracts in which a supplier promises to charge higher prices to the contracting firm's competitors than it charges to the contracting firm." 81 As a result, he proposes that such contracts be illegal per se. 82 Once again, there is no need to show an efficiency creating potential if the arrangement does not increase market power; Hovenkamp offers no explanation of how the contracts he describes could possibly do that. That aside, however, there is not only a rational efficiency explanation for such contracts, there is an obvious one. ${ }^{83}$

Such differential prices are one way to solve the type of free-rider problem involved in Klor's Inc. v. Broadway-Hale Stores, Inc. ${ }^{84}$ and Continental T.V., Inc. v. GTE Sylvania Inc. ${ }^{85}$ In both cases, suppliers wanted their retailers to provide point-of-sale services for the supphiers' product. Retailers are reluctant to provide such services if other retailers can free ride on their efforts. The suppliers in Klor's tried to solve this problem by refusing to supply the free rider. ${ }^{86}$ In GTE Sylvania, the supplier limited the locations through which its product could be sold. ${ }^{87}$ In either case, however, suppliers could have alleviated the problem by charging putative free riders higher prices than they charged firms providing the desired services. The higher wholesale prices to free riders would prevent them from undercutting the retailers who provided local services. Thus, the cooperating retailers would have a continuing incentive to provide the local services desired by the suppliers.

Such promises by suppliers to cooperating retailers would contribute to efficiency by reducing free riding without, as long as they are strictly intrabrand restrictions, creating or increasing market power. Yet Professor Hovenkamp's analysis leads him to conclude that such promises

purpose of property rights. They enable investors to recover returns on investments, thereby constituting the basis of a market economy.

81. Hovenkamp, supra note 78 , at 1317 .

82. Id. at $1317-18$.

83. See Liebeler, Integration and Competition, in VERTICAL INTEGRATION IN THE OIL INDUSTRY 5, 13-14 (E. Mitchell ed. 1976) (price differentiation to prevent free riding on product information); Liebeler, Let's Repeal It, 45 ANTITRUST L.J. 18, 40-41 (1976) (assailing one of RobinsonPatman Act's underlying assumptions: "price differences always favor large buyers and never result in lower prices throughout the market"); see also Liebeler, Book Review, 66 CALIF. I. REV. 1317, 1324 (1978) (refusals to deal can be the same economic phenomenon as certain price discrimination).

84. 359 U.S. 207 (1959).

85. 433 U.S. 36 (1977).

86. 359 U.S. at 209.

87. 433 U.S. at 38 . 
should be illegal per se. Thus does the "strategic behavior" approach to antitrust turn the consumer welfare model upside down.

No one has claimed that the Chicago approach is perfect. But it need fear not from the likes of this. 